\title{
Impact of diets with a high content of greaves- meal protein or carbohydrates on faecal characteristics, volatile fatty acids and faecal calprotectin concentrations in healthy dogs
}

Ingrid Hang ${ }^{1 *}$, Romy M Heilmann², Niels Grützner ${ }^{2}$, Jan S Suchodolski ${ }^{2}$, Jörg M Steiner ${ }^{2}$, Faik Atroshi ${ }^{1}$, Satu Sankari ${ }^{1}$, Anu Kettunen ${ }^{3}$, Willem M de Vos ${ }^{4,5}$, Jürgen Zentek ${ }^{6}$ and Thomas Spillmann ${ }^{1}$

\begin{abstract}
Background: Research suggests that dietary composition influences gastrointestinal function and bacteria-derived metabolic products in the dog colon. We previously reported that dietary composition impacts upon the faecal microbiota of healthy dogs. This study aims at evaluating the dietary influences on bacteria-derived metabolic products associated with the changes in faecal microbiota that we had previously reported. We fed highcarbohydrate starch based (HCS), [crude protein: $194 \mathrm{~g} / \mathrm{kg}$, starch: $438 \mathrm{~g} / \mathrm{kg}$ ], high-protein greaves-meal (HPGM), [crude protein: 609 g/ $/ \mathrm{kg}$, starch: $54 \mathrm{~g} / \mathrm{kg}$ ] and dry commercial (DC), [crude protein: $264 \mathrm{~g} / \mathrm{kg}$, starch: $277 \mathrm{~g} / \mathrm{kg}$ ] diets, and studied their effects on the metabolism of the colonic microbiota and faecal calprotectin concentrations in five Beagle dogs, allocated according to the Graeco-Latin square design. Each dietary period lasted for three weeks and was crossed-over with washout periods. Food intake, body weight, and faecal consistency scores, dry matter, pH, ammonia, volatile fatty acids (VFAs), and faecal canine calprotectin concentrations were determined.
\end{abstract}

Results: Faecal ammonia concentrations decreased with the HCS diet. All dogs fed the HPGM diet developed diarrhoea, which led to differences in faecal consistency scores between the diets. Faecal pH was higher with the HPGM diet. Moreover, decreases in propionic and acetic acids coupled with increases in branched-chain fatty acids and valeric acid caused changes in faecal total VFAs in dogs on the HPGM diet. Faecal canine calprotectin concentration was higher with the HPGM diet and correlated positively with valeric acid concentration.

Conclusions: The HPGM diet led to diarrhoea in all dogs, and there were differences in faecal VFA profiles and faecal canine calprotectin concentrations.

Keywords: Canine, The metabolism of the colonic microbiota, Volatile fatty acids, Faecal canine calprotectin

\section{Background}

Bacterial metabolic activity in the large intestine is influenced by the composition of the microbiota, the colonic transit time of the chyme, and the intraluminal $\mathrm{pH}$ [1]. It is also closely related to the optimal absorptive functioning of the colon. In vitro and in vivo studies have shown that the final products of bacterial fermentation mostly depend on the chemical composition of the chyme that

\footnotetext{
*Correspondence: Ingrid.Moistus@helsinki.fi

'Department of Equine and Small Animal Medicine, University of Helsinki, Helsinki, Finland

Full list of author information is available at the end of the article
}

reaches the large intestine [2,3]. For instance, if there is a lack of carbohydrates (e.g., wheat, maize) in the diet, the microorganisms ferment amino acids into short-chain fatty acids (SCFAs) and ammonia to obtain energy [4]. A sufficient throughput of carbohydrate leads to a decrease in luminal nitrogenous compounds and an increase in faecal bacterial mass [5]. The chemical composition of the digesta/chyme, the amounts of substrates, and the physical form of the food affect the microbial fermentation [6]. The physical form of the diet depends on the manufacturing process of the diet. Therefore, the latter also affects the characteristics of the microbial fermentation. Evidence for

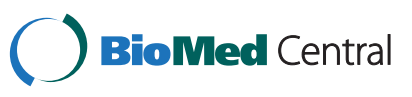


this was provided by a study, on food processing [7]. That study showed that when dogs were fed canned food with poultry and/or beef as the protein source, they had lower total faecal VFAs, but higher levels of faecal valeric, propionic, and branched-chain fatty acids (BCFA) than dogs that were fed commercial dry food with poultry as the protein source [7].

Various studies have shown that diets can impact upon intestinal health and lead to an increased faecal water content and/or high faecal ammonia concentrations. Such changes are mainly due to the protein source $[4,8-11]$ and protein concentration $[4,12,13]$, followed by the carbohydrate concentration of the diet $[4,14,15]$. The induction of mucosal inflammation is an important pathogenic negative outcome of an impact that diets can have upon intestinal health. Methods for assessing colonic inflammation in humans include the histological evaluation of colonic biopsies and the measurement of faecal biomarkers such as calprotectin, lactoferrin, or polymorphonuclear neutrophil elastase [16,17]. A lack of species-specific faecal biomarkers in dogs has prompted the use of endoscopic sampling of the intestinal mucosa under general anaesthesia for the collection of colonic biopsies [18]. Faecal calprotectin is a $\mathrm{Ca}^{2+}$ - and $\mathrm{Zn}^{2+}$ binding protein that is a sensitive but nonspecific biomarker of intestinal inflammation [19,20]. It is also a protein that has bacteriostatic and fungistatic properties $[21,22]$, which protects the intestinal epithelia against infection and contributes to the innate immunity of the host. Bacteriostatic effects of calprotectin were found against Listeria monocytogenes, Salmonella enterica spp. enterica serovar Typhimurium [23]. Calprotectin is expressed mostly by neutrophils, monocytes [24] and activated macrophages [25], but small amounts were also found to be expressed by keratinocytes [26]. Furthermore, calprotectin levels are increased in serum and other body fluids of patients that suffer from rheumatoid arthritis or from cystic fibrosis, which can be considered to be supporting evidence for its usefulness as a marker of inflammation $[27,28]$ and also for the contribution it makes to the host's defence mechanism [29]. Recently, a radioimmunoassay for the quantification of canine calprotectin in serum and faeces was developed and analytically validated $[30,31]$.

To the best of our knowledge, experimental studies in dogs that assess canine faecal characteristics, VFAs and their associations with intestinal inflammatory markers are lacking. The current study is the hitherto unreported part of a previously published study [32], in which we investigated the effects of the above mentioned diets on canine faecal microbiota. In that study, we found that faecal samples from the greaves-meal diet fed, dogs favoured growth of species of Fusobacteriales. It is important to note that Fusobacteriales are potential pathogens for humans [33-35]. Additionally, we reported Coriobacteriales in dog faeces: a finding that was reported in only one other recent study [36]. The hypothesis for the current study was that the high protein greaves-meal diet influences the measured faecal parameters, as it was found to remarkably increase the faecal populations belonging to the order Fusobacteriales [32]. Therefore, our aim was to study whether the effect of dietary greaves-meal and maize starch on faecal microbiota can be associated with altered faecal characteristics, VFAs, and canine faecal calprotectin.

\section{Results}

The HPGM diet increased the faecal consistency score $(p<0.01)$ and it led to diarrhoea in all the dogs. Faecal $\mathrm{pH}$ was higher for the HPGM and the HCS diets than for the DC diet $(p<0.01)$. Faecal ammonia concentrations were $(p=0.01)$ lower for the HCS diet than for either the HPGM or the DC diet feeding periods (Table 1).

The total VFA concentrations were lowest $(p<0.01)$ for the HPGM diet. This reduction could be partly explained by the lower concentrations of acetic acid $(p<0.01)$ and of propionic acid $(p<0.01)$, which both accounted for the largest proportion of the VFAs measured. Although butyric acid was somewhat lower for the HPGM diet compared to the DC diet there was no difference between those diets $(p=0.08)$. Valeric acid and the BCFA concentrations measured were higher for the HPGM diet $(p<0.01$ and $p=0.02$, respectively) compared with the DC and HCS diets. The faecal canine calprotectin concentrations remained within the established reference interval [31], but were higher for the HPGM diet (Kruskal-Wallis test, $p=0.01$ ) than either the HCS or the DC diet, and they correlated positively with valeric acid $(p<0.01)$.

\section{Discussion}

This study investigated the influence of feeding diets with either high dietary protein (from its greaves-meal content) or high carbohydrate (from its high maize starch content) on food intake, body weight, faecal consistency scores, faecal dry matter, $\mathrm{pH}$, ammonia, VFAs, and levels of faecal canine calprotectin.

None of the three diets used in this study affected food intake or body weight of the dogs differently.

The source and concentration of the dietary carbohydrate and/or protein reaching the colon can alter conditions in the colon, by changing the fermentation characteristics and the faecal microbiota $[14,37,38]$. Maize and greaves-meal were respectively used in the current study as a source of carbohydrate and protein. It is known from previous studies that maize and greavesmeal are highly digested in the small intestine $[8,39,40]$. To our knowledge diets with such high maize starch or 
Table 1 Analysis of body weight and faecal consistency scores, dry matter, $\mathrm{pH}$ and $\mathrm{NH}_{3}$ ( $\mathrm{n}=\mathbf{3}$ faecal samples for each variable per diet period) of 5 dogs

\begin{tabular}{|c|c|c|c|c|c|c|}
\hline Variable & Baseline (DC) & $\mathrm{DC}^{1}$ & HPGM $^{2}$ & $\mathrm{HCS}^{3}$ & $\begin{array}{c}\text { Kruskal-Wallis } \\
p \text {-value }\end{array}$ & $\begin{array}{c}\text { Mixed model } \\
p \text {-value }\end{array}$ \\
\hline Body weight, kg & $19.0[18.3-19.3]^{\mathrm{A}}$ & $19.78[18.15-21.10]^{\mathrm{A}}$ & $20.00[18.60-21.65]$ & $19.40\left[\begin{array}{c}18.80-20.85] \\
A\end{array}\right.$ & $>0.10$ & $>0.10$ \\
\hline Faecal consistency score & $2.5[2.0-3.0]^{\mathrm{B}}$ & $2.5[2.0-3.0]^{\mathrm{B}}$ & $4.0[4.0-5.0]^{\mathrm{A}}$ & $2.5[2.0-3.0]^{\mathrm{B}}$ & $<0.01$ & $<0.01$ \\
\hline Faecal dry matter, $\%$ & $32.2[30.1-36.2]^{\mathrm{A}}$ & $32.4[30.6-35.4]^{\mathrm{A}}$ & $32.2[13.6-35.9]^{\mathrm{A}}$ & $32.5[29.8-35.7]^{\mathrm{A}}$ & $>0.10$ & $>0.10$ \\
\hline Faecal pH & $6.9[6.8-7.1]^{A, B}$ & $6.7[6.5-7.0]^{\mathrm{B}}$ & $7.5[6.6-7.9]^{A}$ & $7.2[7.0-7.5]^{\mathrm{A}, \mathrm{B}}$ & $<0.01$ & $<0.01$ \\
\hline $\begin{array}{l}\text { Faecal } \mathrm{NH}_{3}, \mu \mathrm{g} / \mathrm{g} \text { wet } \\
\text { faeces }\end{array}$ & $1245 \underset{\mathrm{A}}{[982-1}$ 482] & $1079 \underset{B}{[693-1468]^{A}}$ & $1191[710-1778]^{\mathrm{A}}$ & $835[657-1,162]^{\mathrm{B}}$ & 0.03 & 0.01 \\
\hline
\end{tabular}

${ }^{1} D C$ : dry commercial diet.

${ }^{2}$ HPGM: high-protein greaves-meal diet.

${ }^{3} \mathrm{HCS}$ : high-carbohydrate starch based diet.

Values are expressed as medians and ranges [min-max]. For each variable, diets not sharing a common superscript (A, B) are significantly different at $\mathrm{p}<0.05$ and are marked in bold.

greaves-meal concentrations have not been used previously in studies.

In our study, the HCS diet did not affect the faecal parameters any differently from the DC diet, except for faecal $\mathrm{pH}$ and ammonia. Faecal $\mathrm{pH}$ was higher for dogs fed the HPGM diet than when they were fed either the HCS or the DC diets (Table 1). This finding is consistent with those of previous studies, in which protein-rich diets led to increases in faecal $\mathrm{pH}[7,9]$. Faecal ammonia was lowest when the dogs were fed the HCS diet as expected. The ammonia fluctuations could be explained by two mechanisms that require further investigation. First, a sufficient carbohydrate supply to the large intestine in dogs fed the HCS diet, led to a decrease in luminal nitrogenous compounds as reported earlier [5]. Second, when the dogs were fed the HCS diet decreased amounts of protein that reached the hindgut for subsequent fermentation. However, the forenamed mechanisms are hypothetical as the amount of carbohydrates and protein reached to the hindgut was not measured in this study.

There was no dietary effect on faecal dry matter. Nevertheless, the high concentration of dietary protein of the HPGM diet used in our study led to diarrhoea in all the dogs (Table 1). The reason for not reaching statistical significance could be due to the large variation between faecal samples within the same dietary sampling period. This in turn, could be due to the small number of dogs $(n=5)$ allocated to the study. Further, substantial variations in faecal dry matter between dogs that received the same dietary treatment and a lack of correlation between faecal moisture and faecal consistency score has also been reported in earlier studies [41-43].

Our finding on the undesirable effects of dietary animal proteins on faecal consistency agrees with the results of previous studies [8-12]. Furthermore, the only previous study used bacterial culture methods for the assessment of dietary effects on the faecal microbiota, and it showed an increased number of Clostridium perfringens in dogs fed animal (poultry or beef) protein [7]. This is consistent with an increased number of $C$. perfringens colonies and decreased counts of Bifidobacterium organisms reported in dogs that were fed a low-quality protein diet [8]. In our previous study, the faecal samples obtained from dogs fed the high protein-greaves-meal treatment contained bacterial species that belonged to the orders Clostridiales, Coriobacteriales, and especially members of the order Fusobacteriales [32]. Fusobacteriales have been implicated to play a role in many different inflammatory processes, including colonic inflammation [33-35]. Therefore, it could be hypothesised that the diarrhoea observed in all dogs fed the HPGM diet was probably associated with the amount and/or quality of protein, which might change the intestinal microbiota and their metabolic activity [9]. Alternatively, it could be due to the lower levels of carbohydrates that enter the large intestine, which lead to the abundance of bacteria belonging to the order of Fusobacteriales [32].

In the present study, the high levels of greaves-meal (the high protein diet) led to a decrease in total VFAs that were mainly attributable to decreases in acetic and propionic acids (Table 2). In contrast, the concentration of faecal valeric acid increased for the HPGM diet. It has been shown in previous studies that there are differences between protein sources in terms of fermentation end products [44], which result in higher proportions of valeric and acetic acids in the canine colon arising from the fermentation of undigested proteins [45]. Acetic acid is produced and excreted by the fermentation activities of acetic acid producing bacteria (e.g., Acetobacter, B. subtilis) [46]. It could be hypothesized that the decrease in faecal acetic acid found in our study for the HPGM diet could be associated with: a) a lower amount of acetic acid bacteria present in the hindgut due to reduced levels of carbohydrate entering the large intestine/colon; or b) it could be due to the high amounts of greaves-meal entering the large intestine. It could also be a combination of both a) and b). 
Table 2 Canine faecal volatile fatty acid and calprotectin concentrations ( $\mathbf{n}=\mathbf{3}$ faecal samples for each variable per diet period) of 5 dogs

\begin{tabular}{|c|c|c|c|c|c|c|}
\hline Fecal variable & Baseline (DC) & $\mathrm{DC}^{1}$ & HPGM $^{2}$ & $\mathrm{HCS}^{3}$ & $\begin{array}{c}\text { Kruskal-Wallis } \\
p \text {-value }\end{array}$ & $\begin{array}{c}\text { Mixed model } \\
p \text {-value }\end{array}$ \\
\hline Total VFA, mM & $196[165-221]^{A}$ & $195[165-239]^{A}$ & $137\left[^{7} 5.0-192\right]^{B}$ & $176[152.3-198]^{A}$ & 0.01 & $<0.01$ \\
\hline Acetic acid, mM & $118[90.0-135]^{A}$ & $118.9[93.9-144]^{A}$ & $71.0[47.8-105]^{B}$ & $96.9[83.5-111]]^{A, B}$ & $<0.01$ & $<0.01$ \\
\hline Propionic acid, mM & $49.3[45.3-55.9]^{\mathrm{A}}$ & $51.1[33.5-63.8]^{\mathrm{A}}$ & $25.2[7.1-31.5]^{B}$ & $21.1[14.0-29.9]^{\mathrm{A}}$ & 0.02 & $<0.01$ \\
\hline Butyric acid, mM & $21.3[14.8-27.8]^{\mathrm{A}}$ & $21.3[14.8-27.8]^{A}$ & $16.8[9.0-23.6]^{\mathrm{A}}$ & $21.1[14.0-29.9]^{\mathrm{A}}$ & 0.10 & 0.08 \\
\hline Valeric acid, mM & $0.4[0.0-0.5]^{B}$ & $0.4[0.0-0.8]^{B}$ & $9.8[0.0-15.3]^{A}$ & $0.6[0.4-6.6]^{\mathrm{B}}$ & $<0.01$ & $<0.01$ \\
\hline BCFA, mM & $8.1[6.8-12.1]^{A, B}$ & $8.3[5.6-12.4]^{A, B}$ & $13.1[2.2-18.9]^{\mathrm{A}}$ & $8.2[5.5-12.2]^{B}$ & 0.10 & 0.02 \\
\hline Calprotectin, $\mu \mathrm{g} / \mathbf{g}$ & $4.6[2.9-7.5]^{\mathrm{B}}$ & $3.0[2.9-20.6]^{\mathrm{B}}$ & $25.0[12.0-113.4]^{\mathrm{A}}$ & $8.8[5.7-22.9]^{A, B}$ & 0.01 & $<0.01^{*}$ \\
\hline
\end{tabular}

*The ANOVA $p$-value was calculated for this variable due to lack of measurement points.

${ }^{1} D C$ : dry commercial diet.

${ }^{2}$ HPGM: high-protein greaves-meal diet.

${ }^{3} \mathrm{HCS}$ : high-carbohydrate starch based diet.

Values are expressed as medians and ranges [min-max]. For each variable, diets not sharing a common superscript $(\mathrm{A}, \mathrm{B})$ are significantly different at $\mathrm{p}<0.05$ and are marked in bold.

We also recorded an increase in faecal BCFAs $(p=0.02)$ in dogs fed the HPGM diet. It is generally known that BCFAs are formed by the metabolism of branched-chain amino acids such as valine, leucine, and isoleucine following the breakdown of polypeptides $[47,48]$. Consequently, the increase in faecal BCFAs measured for the HPGM diet might be simply due to the large amounts of protein entering the hindgut. An increase in the concentration of BCFAs in stools has also been reported in humans who were fed a diet containing supplemental dietary protein based on whey, casein, and lactalbumin [1].

Calprotectin was increased in the faeces of dogs fed the HPGM diet (Table 2) and it was also positively correlated with the concentration of faecal valeric acid. In human medical studies, calprotectin is reported to be a sensitive but nonspecific biomarker of intestinal inflammation $[19,20]$ as the calprotectin parameter is not sensitive enough for the definitive differentiation between underlying intestinal diseases [49-51]. Calprotectin also has bacteriostatic and fungistatic properties [21,22] that have been suggested to protect the intestinal epithelium against infection, thus contributing to the innate immunity of the host. Increased concentrations of faecal calprotectin were detected in patients with Crohn's disease [20,51], ulcerative colitis [49,50], and colorectal cancer [52]. Recently, the development and analytical validation of a species-specific laboratory method for the measurement of canine calprotectin in faeces for faecal calprotectin has been published [31]. In our study, increases in faecal canine calprotectin concentrations, occurred only when dogs were fed the HPGM diet. This increase also correlated positively with faecal valeric acid levels. Interestingly, the faecal samples from dogs fed the greaves-meal diet had a high preponderance of Fusobacteriales bacteria [32]: an order of bacteria that has been suspected to play a pathogenic role in human intestinal inflammation [34-36]. Therefore, one could hypothesize that Fusobacteria could produce branched VFAs and valeric acid from protein break-down products [53]. Moreover, some Fusobacteria could act as pathogens, which may cause intestinal inflammation that would result in increased faecal calprotectin levels. Therefore, valerate and calprotectin would be expected to be correlated. However, further investigation is needed to assess the possible role of Fusobacteriales spp., and increased quantities of bacterially-derived faecal valeric acid and faecal calprotectin in cases of canine intestinal inflammation.

\section{Conclusions}

Feeding a high protein diet with a high content of greaves-meal to dogs led to diarrhoea in all the dogs of our study. Intestinal metabolic (VFA profiles, ammonia, and $\mathrm{pH}$ ) and inflammatory (faecal calprotectin) parameters for the HPGM diet differed from those of the HCS or the DC diet. We conclude that the HPGM could have mediated the following alternative scenarios: HPGM caused high concentrations of protein to enter the hindgut, HPGM caused lower quantities of maize starch to enter the hindgut, or a combination of both of these. Any of these alternative mechanisms could lead to diarrhoea mediated by changes in the intestinal microbiota and their metabolic activity. Such changes could possibly lead to intestinal mucosal inflammation.

\section{Methods}

\section{Animals and diets}

This study is the hitherto unreported part of a previously published study [32] and was designed as a crossover study. Five adult intact male Beagle $\operatorname{dogg}^{\mathrm{a}}$ (age: 5 years; 
body weight: $18-22 \mathrm{~kg}$ ) were housed individually according to European Union guidelines in indoor-pens (dimension 3.3-6.9 $\mathrm{m}^{2}$ ) at the Experimental Animal Unit of Helsinki University, Finland. The periods included a baseline, the three treatment diets with washout periods. Over the whole study, each dog received all the three diets separated by washout but in different sequence from one another. All dogs entered the baseline period at the same time, followed by a different sequence of dietary treatments and washout periods, which were crossedover as the study progressed (Table 3 ). The experimental protocol was approved by the local Ethics Committee for Animal Use and Care in Helsinki, Finland (Animal Experiment Board, Regional State Administrative Agency for Southern Finland, license ESLH-2008-04002/ Ym-23). Dogs were exposed to artificial light from 7-16. The environmental temperature indoors was maintained within a range of $15-24^{\circ} \mathrm{C}$. The Beagles were considered to be large-framed but not obese as based on visual inspection.

All dogs received a dry commercial $\operatorname{diet}^{\mathrm{b}}$ (DC diet comprising: crude protein $264 \mathrm{~g} / \mathrm{kg}$; starch, $277 \mathrm{~g} / \mathrm{kg}$ ), a high-protein greaves-meal diet (HPGM diet comprising: crude protein, $609 \mathrm{~g} / \mathrm{kg}$; starch, $54 \mathrm{~g} / \mathrm{kg}$ ), or a highcarbohydrate starch based diet (HCS diet comprising: crude protein, $194 \mathrm{~g} / \mathrm{kg}$; starch, $438 \mathrm{~g} / \mathrm{kg}$ ) as previously published [32]. In addition to being one of the treatments, the DC was used as the baseline diet and also as the washout diet. Water was provided freely for the duration of the study.

\section{Sample collection and handling}

Fresh naturally-passed faecal samples were collected immediately after defecation on the last three consecutive days of every dietary treatment period for every dog. Each treatment period counted sequentially from $\mathrm{d} 1$ at the beginning of the study baseline as the study progressed to $d 129$ when the study treatments and sampling ended (Table 3). Thus, the baseline period [Baseline $(\mathrm{DC})$ ] on $\mathrm{d} 10-12$, during the diet periods on $\mathrm{d}$ $15-17$, and for the washout periods on $\mathrm{d} 22-24$. For example, the sampling time points in the feeding sequence for $\operatorname{dog} 2$ (Table 3) were d 10-12 was the end of feeding the baseline DC diet, $\mathrm{d} 29-31$ was the end of feeding the HPGM diet, d 57-59 was the end of first washout period with the DC diet, $d 78-80$ was the end of HCS diet, $d$ 106-108 was the end of second washout period with the DC diet, and d 127-129 was the end of DC diet period. Samples were thoroughly homogenized and faecal $\mathrm{pH}$ was measured immediately after collection. Several 1 -g aliquots were then placed in preweighed sterile Sarstedt faecal collection tubes ${ }^{\mathrm{c}}$ and frozen at $-20^{\circ} \mathrm{C}$ for further analyses of ammonia, dry matter, and VFAs. A subsample was frozen at $-80^{\circ} \mathrm{C}$ for the measurement of faecal canine calprotectin.

For ammonia measurement, 1-g faecal samples were pretreated by thorough mixing with $3 \mathrm{~mL}$ of $1 \mathrm{~mol} / \mathrm{L}$ $\mathrm{HClO}_{4}$ before freezing at $-20^{\circ} \mathrm{C}$. Faecal samples frozen at $-80^{\circ} \mathrm{C}$ were shipped on dry ice to the Gastrointestinal Laboratory at Texas A\&M University, USA for further analyses of faecal canine calprotectin concentrations.

\section{Clinical parameters}

Body weight, food intake, and faecal consistency scores were determined daily, as described previously [54]. Dogs were weighed once a week in the morning, before feeding. For food intake assessment, the amount of food allocated to each dog was calculated according to the individual energy requirements for each dog before entering the study. The amount of food given in grams was weighed before it was given to each dog. Food weighing after feeding was not needed as all the dogs ate everything at every feeding point.

\section{Fecal parameters}

Faecal dry matter, $\mathrm{pH}$, ammonia, VFA profiles, and canine calprotectin concentrations were measured in all faecal samples. Faecal dry matter was determined by overnight oven-drying of each sample at $103^{\circ} \mathrm{C}$, as previously described [7]. Faecal pH was measured by using a digital $\mathrm{pH}$-meter ${ }^{\mathrm{d}}$, as previously described $[7,55]$. In order to ensure accuracy, the means of 3 replicate measurements were calculated and entered into the data analysis. Faecal ammonia concentrations were measured

Table 3 The feeding sequence of the HPGM, HCS, and DC diets over six feeding periods

\begin{tabular}{|c|c|c|c|c|c|c|}
\hline \multirow{2}{*}{$\frac{\text { Dog }}{1}$} & \multirow{2}{*}{$\frac{\text { Baseline (DC) }}{\text { DC diet }}$} & \multicolumn{5}{|c|}{ Diet (DC, HPGM, and HCS) and washout periods (WO) } \\
\hline & & $D C^{1}$ & $\mathrm{HPGM}^{2}$ & $W^{3}$ & $\mathrm{HCS}^{4}$ & WO \\
\hline 2 & DC diet & HPGM & Wo & $\mathrm{HCS}$ & WO & DC \\
\hline 3 & DC diet & $\mathrm{HC}$ & WO & DC & HPGM & WO \\
\hline 4 & DC diet & DC & HCS & WO & HPGM & WO \\
\hline 5 & DC diet & $\mathrm{HCS}$ & wo & HPGM & WO & DC \\
\hline
\end{tabular}

${ }^{1} D C$ : dry commercial (DC) diet.

${ }^{2} H P G M$ : high-protein greaves-meal diet.

${ }^{3}$ WO: washout period with the DC diet.

${ }^{4} H C S$ : high-carbohydrate starch based diet. 
by an enzymatic method [56], using an ammonia assay kit $^{\mathrm{e}}$ adapted for an automated chemistry analyzer ${ }^{\mathrm{f}}$, according to the manufacturer's instructions.

The faecal VFA profiles, had determinations of propionic acid, acetic acid, butyric acid, valeric acid, and BCFA (isobutyric and isovaleric acid) and were measured, using a modified version of previously described protocols [7,57] as follows: $0.5 \mathrm{~g}$ of faeces were mixed with $4.25 \mathrm{~mL}$ of deionized water and $250 \mu \mathrm{L}$ of a premade solution of an internal standard ${ }^{\mathrm{g}}$, the mixture was then vortexed for $4 \mathrm{~min}$, centrifuged at $5000 \times \mathrm{g}$ at $+4^{\circ} \mathrm{C}$ for $15 \mathrm{~min}$, followed by centrifugation of $1 \mathrm{~mL}$ of the supernatant at $10000 \times g$ at $+4^{\circ} \mathrm{C}$ for $10 \mathrm{~min}$. The clear supernatant was then filtered into a $1.5-\mathrm{mL}$ crimp vial by using a syringe filter ${ }^{\mathrm{h}}$. For measuring VFA concentrations, $1 \mu \mathrm{L}$ of the filtrate was used for gas chromatography with a flame ionization detector ${ }^{\mathrm{i}}$.

Faecal calprotectin concentrations were determined at the Gastrointestinal Laboratory at Texas A\&M University. The faecal samples for all $\operatorname{dogs}(n=5)$ for calprotectin determinations were collected on the last three consecutive days at the end of each dietary period then pooled and thoroughly mixed. A previously developed and analytically validated in-house radioimmunoassay was used [31].

\section{Data handling and statistical analyses}

Data are presented as medians and ranges for the minimum and maximum and were analyzed by Excel and JMP 7.0. The data of samples taken for the last three consecutive days at the end of each diet period were assessed for all parameters analysed, except faecal calprotectin concentration. For each dog, the means of food intake, body weight, and faecal consistency score, faecal dry matter, $\mathrm{pH}$, ammonia, and VFAs for three days were calculated and each parameter entered as a single datum. The faecal calprotectin concentrations represent one pooled sample of three consecutive days (one faecal sample per day) at the end of each diet period. The significance of the dietary effect was determined, using a mixed-effect model that included the parameters dog, $\operatorname{dog} \mathrm{X}$ diet interaction, and the time nested under the diet as random effects. The non-parametric KruskalWallis test was used for evaluating the differences among the diet treatments. Pair-wise Spearman correlation coefficients were calculated for all parameters measured. Unless otherwise stated, the $p$-values reported refer to the mixed-effect model. Significance was set at below 0.05 for all statistical analyses.

\section{Endnotes}

${ }^{a}$ Beagle dogs, origin: Harlan-Winkelmann, Borchen, Germany;
${ }^{\mathrm{b}}$ Mastery Pro Adult Maintenance, Raili Pispa Oy, Muurla, Finland;

${ }^{\mathrm{c}}$ Faecal collection tube $(101 \times 16.5 \mathrm{~mm}$; incl. spatula $)$, Sarstedt Oy, Vantaa, Finland;

${ }^{\mathrm{d}}$ Knick pH-Meter 761 Calimatic, Knick Elektronische Messgeräte $\mathrm{GmbH} \& \mathrm{Co}, \mathrm{KG}$, Berlin, Germany;

${ }^{\mathrm{e}}$ Ammonia Assay Kit, Megazyme International Ireland Ltd., Wicklow, Ireland;

${ }^{\mathrm{f}}$ KONE Pro, Thermo Fisher Scientific, Vantaa, Finland;

g Internal standard: $140 \mathrm{mM}$ 4-methylvaleric acid in formic acid, Helsinki, Finland;

${ }^{\mathrm{h}}$ Acrodisc LC $13 \mathrm{~mm}$ with a $0.2-\mu \mathrm{m}$ polyvinylidene fluoride (PVDF) membrane, $4450 \mathrm{~T}$, Pall Corporation, Port Washington, New York, USA;

${ }^{\mathrm{i}}$ Agilent 7890A and 7683, Agilent Technologies, Espoo, Finland.

\section{Abbreviation}

$\mathrm{HClO}_{4}$ : Perchloric acid.

\section{Competing interests}

The authors declare that they have no competing interests.

\section{Authors' contributions}

$\| H, W M V, J Z$ and TS conceived the study design; $I H$ performed the sample collection; NG, RMH, JSS and JS performed the faecal calprotectin analysis; $I H$ and SS performed all analyses except for the faecal calprotectin analysis; AK and $\mathrm{IH}$ performed the statistical analyses; all of the authors contributed to the writing of the manuscript. All authors read and approved the final manuscript.

\section{Acknowledgements}

The authors thank the Archimedes Foundation and the Helvi Knuuttila Foundation for financial support. Kirsi Laukkanen, Merja Pöytäkangas, and Outi Huurinainen are thanked for their technical support at the University of Helsinki. Susanna Alaja is thanked for her statistical support.

\section{Author details}

${ }^{1}$ Department of Equine and Small Animal Medicine, University of Helsinki, Helsinki, Finland. ${ }^{2}$ Gastrointestinal Laboratory, Department of Small Animal Clinical Sciences, College of Veterinary Medicine and Biomedical Sciences, Texas A \& M University, 4474 TAMU, College Station, TX 77843, USA. ${ }^{3}$ Savcor Group Ltd, Mikkeli, Finland. ${ }^{4}$ Department of Basic Veterinary Sciences, University of Helsinki, Helsinki, Finland. 'Laboratory of Microbiology, Wageningen University, Wageningen, The Netherlands. ${ }^{6}$ Institute of Animal Nutrition, Section of Veterinary Medicine, Free University Berlin, Berlin, Germany.

Received: 23 November 2012 Accepted: 25 September 2013

Published: 9 October 2013

\section{References}

1. Geypens B, Claus D, Evenepoel P, Hiele M, Maes B, Peeters M, Rytgeerts P, Ghoos $Y$ : Influence of dietary protein supplement on the formation of bacterial metabolites in the colon. Gut 1997, 41:70-76.

2. McBurney MI, Thompson LU, Cuff DJ, Jenkins DJA: Comparison of ileal effluents, dietary fibers, and whole foods in predicting the physiologic importance of colonic fermentation. Am J Gastroenterol 1988, 83:536-540.

3. Hiele MI, Ghoos YF, Rutgeerts PJ, Vantrappen GR, Schoorens D: Influence of nutritional substrates on the formation of volatiles by the faecal flora. Gastroenterology 1991, 100:1597-1602.

4. Nery J, Goudez R, Biourge V, Tournier C, Leray V, Martin L, Thorin C, Nguyen $P$, Dumon $\mathrm{H}$ : Influence of dietary protein content and source on colonic fermentative activity in dogs differing in body size and digestive tolerance. J Anim Sci 2012, 90:2570-2580. 
5. Cummings $\mathrm{JH}, \mathrm{Hill}$ MJ, Bones ES, Branch WJ, Jenkins DJA: The effect of meat protein and dietary fiber on colonic function and metabolism. II. Bacterial metabolites in feces and urine. Am J Clin Nutr 1979, 32:2094-2101.

6. Macfarlane S, Macfarlane GT: Regulation of short-chain fatty acid production. Proc Nutr Soc 2003, 62:67-72.

7. Zentek J, Fricke S, Hewicker-Trautwein M, Ehinger B, Amtsberg G, Baums C: Dietary protein source and manufacturing processes affect macronutrient digestibility, fecal consistency and presence of fecal Clostridium perfringens in adult dogs. J Nutr 2004, 134:2158-2161.

8. Zentek J: Influence of diet composition on the microbial activity in the gastrointestinal tract of dogs. I. Effect of varying protein intake on the composition of the ileum chyme and the faeces. J Anim Physiol Anim Nutr 1995, 74:43-52

9. Zentek J, Marquart B, Pietrzak T, Ballevre O, Rochat F: Dietary effects in Bifidobacteria and Clostridium perfringens in the canine intestinal tract. J Anim Physiol Anim Nutr (Berl). 2003, 87:397-407.

10. Meyer $\mathrm{H}$, Zentek J, Habernoll H, Maskell I: Digestibility and compatibility of mixed diets and faecal consistency in different breeds of dog. J Vet Med 1999, 46:155-165.

11. Rolfe V, Adams CA, Butterwick R, Batt R: Relationship between fecal consistency and colonic microstructure and absorptive function in dogs with and without nonspecific dietary sensitivity. Am J Vet Res 2002, 63:617-622.

12. Dong G, Zhou A, Yang F, Chen K, Wang K, Dao D: Effect of dietary protein levels on the bacterial breakdown of protein in the large intestine, and diarrhoea in early weaned piglets. Acta Veterinaria et Zootechnica Sinica 1996, 27:293-302.

13. Jha $R$, Leterme $P$ : Feed ingredients differing in fermentable fibre and indigestible protein content affect fermentation metabolites and faecal nitrogen excretion in growing pigs. Animal 2012, 6:603-611.

14. Wong JM, de Souza R, Kendall CW, Emam A, Jenkins DJ: Colonic health: fermentation and short chain fatty acids. J Clin Gastroenterol 2006, 40:235-243.

15. Muir JG, Yeow EGW, Keogh J, Pizzey C, Bird AR, Sharpe K, Dean OK, Macrea FA: Combining wheat bran with resistant starch has more beneficial effects on fecal indexes than does wheat bran alone. Am J Clin Nutr 2004, 79:1020-1028.

16. Langhorst J, Elsenbruch S, Koelzer J, Rueffer A, Michalsen A, Dobos DJ: Noninvasive markers in the assessment of intestinal inflammation in inflammatory bowel diseases: performance of fecal lactoferrin, calprotectin, and PMN-elastase, CRP, and clinical indices. Am J Gastroenterol 2008, 103:162-169.

17. Vieira A, Fang CB, Rolim EG, Klug WA, Steinwurz F, Rossini LG, Candelaria PA Inflammatory bowel disease activity assessed by fecal calprotectin and lactoferrin: correlation with laboratory parameters, clinical, endoscopic and histological indexes. BMC Res Notes 2009, 2:221

18. Sauter SN, Benyacoub J, Allenspach K, Gaschen F, Ontsouka E, Reuteler G, Cavadini C, Knorr R, Blum JW: Effects of probiotic bacteria in dogs with food responsive diarrhoea treated with an elimination diet. $J$ Anim Physiol Anim Nutr (Berl) 2006, 90:269-277.

19. Melling TR, Aabakken $L$, Røseth AG, Osnes M: Faecal calprotectin shedding after short term treatment with non-steroidal anti-inflammatory drugs (NSAIDs). Scand J Gastroenterol 1996, 31:339-344.

20. Tibble JA, Sigthorsson G, Foster R, Scott D, Fagerhol MK, Roseth A, Bjarnason I: High prevalence of NSAID enteropathy as shown by a simple faecal test. Gut 1999, 45:362-366.

21. Miyasaki KT, Bodeau AL, Murthy AR, Lehrer RI: In vitro antimicrobial activity of the human neutrophil cytosolic S-100 protein complex, calprotectin, against Capnocytophaga sputigena. J Dent Res 1993, 72:517-523.

22. Brandtzæg P, Gabrielsen TO, Dale I, Muller F, Steinbakk M, Fagerhol MK: The leucocyte protein L1 (calprotectin): a putative nonspecific defence factor at epithelial surfaces. Adv Exp Med Biol 1995, 371A:201-206.

23. Nisapakultorn K, Ross FK, Herzberg CM: Calprotectin expression inhibits bacterial biding to mucosal epithelial cells. Infect Immun 2001, 69:3692-3696.

24. Dale I, Brandtzæg P, Fagerhol MK: Distribution of a new myelomonocytic antigen (L1) in human peripheral blood leukocytes. Immunofluorescence and immunoperoxidase staining features in comparison with lysozyme and lactoferrin. Am J Clin Pathol 1985, 84:24-34.

25. Odink K, Cerletti N, Bruggen J: Two calcium-binding proteins in infiltrate macrophages of rheumatoid arthritis. Nature 1987, 330:80-82.
26. Wilkinson MM, Busuttil A, Hayward C: Expression pattern of two related cystic fibrosisassociated calcium-binding proteins in normal and abnormal tissues. J Cell Sci 1988, 91:221-230.

27. Berner Berntzen H, Endresen GK, Fagerhol MK, Spiechowicz J, Mowinckel P: Calprotectin (the L1 protein) during surgery in patients with rheumatoid arthritis. Scand J Clin Lab Invest 1991, 51:643-650.

28. Golden BE, Clohessy PA, Russell G, Fagerhol MK: Calprotectin as a marker of inflammation in cystic fibrosis. Arch Dis Child 1996, 74:136-139.

29. Lusitani D, Malawista SE, Montgomery RR: Calprotectin, an abundant cytosolic protein from human polymorphonuclear leukocytes, inhibits the growth of Borrelia burgdorferi. Infect Immun 2003, 71:4711-4716.

30. Heilmann RM, Suchodolski JS, Steiner JM: Purification and partial characterization of canine calprotectin. Biochimie 2008, 90:1306-1315.

31. Heilmann RM, Suchodolski JS, Steiner JM: Development and analytic validation of a radioimmunoassay for the quantification of canine calprotectin in serum and feces from dogs. Am J Vet Res 2008, 69:845-853.

32. Hang I, Rinttila T, Zentek J, Kettunen A, Alaja S, Apajalahti J, Harmoinen J, Vos WM, Spillmann T: Effect of high contents of dietary animal-derived protein or carbohydrates on canine faecal microbiota. BMC Vet Res 2012, 8:90.

33. Citron DM: Update on the taxonomy and clinical aspects of the genus fusobacterium. Clin Infect Dis 2002, 35:22-27.

34. Ohkusa T, Yoshida T, Sato N, Watanabe S, Tajiri H, Okayasu I: Commensal bacteria can enter colonic epithelial cells and induce proinflammatory cytokine secretion: a possible pathogenic mechanism of ulcerative colitis. J Med Microbiol 2009, 58:535-545.

35. Swidsinski A, Dörffel Y, Loening-Baucke V, Theissig F, Rückert JC, Ismail M, Rau WA, Gaschler D, Weizenegger M, Kühn S, Schilling J, Dörffel WV: Acute appendicitis is characterised by local invasion with Fusobacterium nucleatum/necrophorum. Gut 2011, 60:34-40.

36. Wakshlag JJ, Simpson KW, Struble AM, Dowd SE: Negative fecal characteristics are associated with $\mathrm{pH}$ and fecal flora alterations during dietary change in dogs. Intern J Appl Res Vet Med 2011, 9:278-283.

37. Hooda S, Boler BMV, Kerr KR, Dowd SE, Swanson KS: The gut microbiome of kittens is affected by dietary protein:carbohydrate ratio and associated with blood metabolite and hormone concentrations. Br J Nutr 2012, 31:1-10.

38. Morita T, Kasaoka S, Kiriyama S: Physiological functions of resistant proteins: proteins and peptides regulating large bowel fermentation of indigestible polysaccharide. J AOAC Int 2004, 87:792-796.

39. Gajda M, Flickinger EA, Grieshop CM, Bauer LL, Merchen NR, Fahey JGC: Corn hybrid affects in vitro and in vivo measures of nutrient digestibility in dogs. J Anim Sci 2005, 83:160-171.

40. Hesta M, Roosen W, Janssens GPJ, Millet S, Wilde De E: Prebiotics affect nutrient digestibility but not faecal ammonia in dogs fed increased dietary protein levels. Br J Nutr 2003, 90:1007-1014.

41. Sunvold GD, Titgemeyer EC, Bourquin LD, Fahey GC Jr, Garleb KA: Alteration of the fiber and lipid components of a defined-formula diet: effects on stool characteristics, nutrient digestibility, mineral balance, and energy metabolism in humans. Am J Clin Nutr 1995, 62:1252-1260.

42. Propst EL, Flickinger EA, Bauer LL, Merden NR, Fahley GC Jr: A doseresponse experiment evaluating the effects of oligofructose and inulin on nutrient digestibility, stool quality, and fecal protein catabolites in healthy adult dogs. J Anim Sci 2003, 81:3057-3066.

43. Hernot DC, Dumon HJ, Biourge VC, Martin $\sqcup$, Nguyen PG: Evaluation of association between body size and large intestinal transit time in healthy dogs. Am J Vet Res 2006, 67:342-347.

44. Depauw S, Bosch G, Hesta M, Whitehouse-Tedd K, Hendriks WH, Kaandorp J, Janssens GPJ: Fermentation of animal components in strict carnivores: a comparative study with cheetah fecal inoculum. J Anim Sci 2012, 90:2540-2548.

45. Kuzmuk NK, Swanson SK, Tappenden AK, Schook BL, Fahey CGJ: Diet and age affect intestinal morphology and large bowel fermentative end-product concentrations in senior and young adult dogs. J Nutr 2005, 135:1940-1945.

46. Cheryan M: Acetic acid production. In Encyclopedia of Microbiology. San Diego: Academic Press; 2000:13-17.

47. Tjellström B, Stenhammar L, Högberg L, Fälth-Magnusson K, Magnusson KE, Midtvedt T, Sundqvist T, Norin E: Gut microflora associated characteristics in children with celiac disease. Am J Gastroenterol 2005, 100:2784-2788.

48. Macfarlane GT, Gibson GR, Beatty E, Cummings JH: Estimation of shortchain fatty acid production from protein by human intestinal bacteria 
based on branched-chain fatty acid measurements. FEMS Microbiol Ecol 1992, 101:81-88.

49. Fagerhol MK: Calprotectin, a faecal marker of organic gastrointestinal abnormality. Lancet 2000, 356:1783-1784.

50. Røseth AG, Aadland E, Grzyb K: Normalization of faecal calprotectin: a predictor of mucosal healing in patients with inflammatory bowel disease. Scand J Gastroenterol 2004, 39:1017-1020.

51. Tibble J, Teahon K, Thjodleifsson B, Roseth A, Sigthorsson G, Bridger S, Foster R, Sherwood R, Fagerhol M, Bjarnason I: A simple method for assessing intestinal inflammation in Crohn's disease. Gut 2000, 47:506-513.

52. Røseth AG, Kristinsson J, Fagerhol MK, Schjonsby H, Aadland E, Nygaard K, Roald B: Faecal calprotectin: a novel test for the diagnosis of colorectal cancer? Scand J Gastroenterol 1993, 28:1073-1076.

53. Resmer KL, White RL: Metabolic footprinting of the anaerobic bacterium Fusobacterium varium using 1H NMR spectroscopy. Mol Biosyst 2011, 7:2220-2227.

54. Kilpinen S, Spillmann T, Syrjä P, Skrzypczak T, Louhelainen M, Westermarck E: Effect of tylosin on dogs with suspected tylosin-responsive diarrhea: a placebo-controlled, randomized, double-blinded, prospective clinical trial. Acta Vet Scand 2011, 53:26.

55. Zentek J, Marquart B, Pietrzak T: Intestinal effect of mannanoligosaccharides, transgalactooligosaccharides, lactose and lactulose in dogs. J Nutr 2002, 132:1680-1684.

56. Bergmeyer HU, Beutler HO: Ammonia. In Methods of enzymatic analysis $3^{\text {rd }}$ ed., Vol. VIII. Edited by Bergmeyer HU. Cambridge, UK: VCH Publishers (UK) Ltd; 1990:454-461.

57. Tangerman A, Nagengast FM: A gas chromatographic analysis of fecal short-chain fatty acids, using the direct injection method. Anal Biochem 1996, 236:1-8.

doi:10.1186/1746-6148-9-201

Cite this article as: Hang et al:: Impact of diets with a high content of greaves-meal protein or carbohydrates on faecal characteristics, volatile fatty acids and faecal calprotectin concentrations in healthy dogs. BMC Veterinary Research 2013 9:201.

\section{Submit your next manuscript to BioMed Central and take full advantage of:}

- Convenient online submission

- Thorough peer review

- No space constraints or color figure charges

- Immediate publication on acceptance

- Inclusion in PubMed, CAS, Scopus and Google Scholar

- Research which is freely available for redistribution

Submit your manuscript at www.biomedcentral.com/submit
C Biomed Central 